\title{
Digital Empowerment Strategies in the Education Sector for the Linking of Citizens with the Key Sectors of Colombian Society
}

\author{
Iris Jimenez Pitre ${ }^{1 *}$, Geomar Molina-Bolivar ${ }^{1}$ and Raul Martelo Gomez ${ }^{2}$ \\ 'Research Group, BIEMARC, Universidad de La Guajira, Riohacha, Colombia; \\ Colombiaiajimenez@uniguajira.edu.co,gmolina@uniguajira.edu.co \\ 2Research Group, GIMATICA, Universidad de Cartagena, Colombia; \\ rmartelog@unicartagena.edu.co
}

\begin{abstract}
Objective: To develop digital inclusion strategies that could be linked to the Colombians with the key factors of society: Government, education and business. Methods: With the document review, a questionnaire was designed for the collection of data; validated by experts. Reliability was measured through the Cronbach's alpha coefficient, obtaining a value of 0.83 . The instrument had a high reliability with 16 questions of the dimensions: Accessibility, integration and management of employment equity. The Lickert scale was kind of five response options: Very high $=5$, high $=4$, Moderate $=3$, Low $=2$ and very low $=1$. Findings: It is considered that the Colombian citizen has a very high degree in the use of information and communication technologies and access to these to reduce the time requests and procedures performed with state institutions and the private sector. The social environment had forced it to digitally literate through various state agencies as is the case of the universities. The results obtained indicate that the University has the opportunity to train citizens in digital. In addition, to improve the skills of citizens so that they have better possibilities to improve the living conditions and be in keeping with the demands of society. Application/Improvements: The university extension constitutes the academic element suitable to relate the academy with the environment and bring knowledge to the society. In Colombia, the conditions are given to implement policies of digital inclusion; due to the increase in the levels of Internet access and the regulation of inclusion developed by the government through the MinTic.
\end{abstract}

Keywords: Colombian Society, Digital Empowerment, Education Sector, Information and Communication Technologies, Linking of Citizens

\section{Introduction}

This research proposes strategies for digital inclusion, from the universities, to enable the digital empowerment of Colombian citizens, to strengthen the levels of inclusion in society, to build a more equitable society and improve access to decent employment and achieve the development of the country. These strategies should be linked to the Colombians with the key factors of society: government, education and business. In this context $t^{1}$, recognize the role of the universities and describe the knowledge as a factor that generates competitive advantages. The above, is reinforced with the use of information and communication technologies (TIC) in the educa-

${ }^{*}$ Author for correspondence 
tion sector, strengthening in this way the educational processes, which contribute to the formation of citizens, regardless of the distances, having the possibility of using TIC tools. From this point of view, the extension in the Colombian universities becomes a space that fosters the participation of citizens, regardless of their academic level.

It is important to define the variables that relate the dimensions of this study (digital accessibility, digital inclusion, equity and management of employment) and their relationship with TIC. Define TIC as tools required to manage information and provide solutions with direct impact on societies; which are a benchmark in the social psychology, by influencing the new forms of identity construction and its environment ${ }^{2}$. With the rise of new technologies, technological gaps or digital that is produced by the inequalities of access on the part of the citizens. From is perspective the ICT has expanded disclosure of the information to the global level because they have become valuable tools for the transmission of knowledge. In such a way that it requires the formulation of educational strategies for that knowledge to society as a whole ${ }^{3}$. These authors describe Learning Objects (OA), such as digital contextualized entities formed by content and learning activities which can promote teachinglearning processes in virtual environments in such a way that the student must develop skills and strategies to deal appropriately with the different learning situations. It is important to understand that the teaching-learning process is based on three dimensions: 1, Education, which has as its object the integral formation of the individual, 2. The teaching, which is the process by which knowledge and 3 . The learning, which is the process by which a person is trained to resolve situations. This process has been enriched by the inclusion of TIC as a vehicle for learning and benefits such as: The elimination of the barriers of time and space between teacher and student, the flexibilization of teaching, extension of the offer for the student, individualization of teaching and learning throughout life, among others.

For Authors, initiatives such as "Digital Kiosks Lives" in Colombia, facilitate access to TIC to rural popula- tions or of difficult access, contributing with the digital inclusion of these communities 2 . This proposal includes the articulation of virtual environments by means of the online communication between subjects and education that contributes to the individual development of society. Through these initiatives the individual has the opportunity to develop digital skills, be linked to their environment and also with external entities to their community, learning tools, access to entertainment, talent development and management of the employment; it will undoubtedly contribute to the digital inclusion and at the same time promoting equity. For its part, explained that the digital inclusion is a complex that is in training, but that is affected by the privatization of web services ${ }^{4}$. This situation makes them less accessible to people with low incomes, which affects the principle of equity, is the belief that there are a number of citizens' rights that are derived from ICT, such is the case of stay connected and informed, to know the identity of the sender of information, privacy, protection of minors and intellectual property in the network. In this sense, Internet cafes, telecenters and public libraries offer the best opportunity of access to TIC for marginalised communities, due to the fact that these sites are of free access; these spaces, usually people who do not have access to devices such as smart phones, computers, or Internet access $\frac{5,6}{}$.

On the other hand, persons with disabilities are affected by lack of communication and information, it allows them to social inclusion. It is important to generate initiatives that provide opportunities for development in society through the facilities offered by $\mathrm{TIC}^{-5}$. In this sense, this author proposed citizens' initiatives of the laboratories that promote social and technological innovation to reduce social inequalities and asymmetries. Argue that this initiative has been gathering strength in some countries of Latin America, where the engine of innovation are mainly citizens and not so much the companies, universities and governments, since their role changes with the emergence of new institutions ${ }^{7}$. This is mainly because the use of technologies to allow citizens to become the central actors of the process and in that way, the innovative social changes are routed from 
the base up in a pyramidal model and not as traditionally happens, from top to bottom as they do companies and the state (including the formal education sector). In Colombia the conditions are given to establish and implement policies for digital inclusion of empowerment so that every citizen to contribute to the development of the country ${ }^{6.8}$. This statement is to be leveraged in the rapid increase in the levels of Internet access, digital inclusion public policies developed by the Colombian government through the Ministry of Information Technologies and Communications (MinTic) in your project Colombia Digital in the 2016.

\section{Results}

The methodology used in this research is the type actionresearch, with a descriptive design, transactional and field ${ }^{9,10}$. The investigation was based theoretically on the literature review related to the dimensions of the study: Digital accessibility, digital inclusion, equity, employment management and its relationship with TIC. The data collection instruments of the information is based on these theories, as well as the analysis of the results. From the document review, we designed a data collection instrument type questionnaire which was tested for validity by experts. The reliability was measured by means of Cronbach's alpha coefficient with a result of 0.83 which indicates that the instrument is highly reliable ${ }^{11}$. This instrument was organized in 16 questions distributed in four dimensions: Accessibility digital, digital integration, equity and employment management; each dimension had four questions. The questionnaire had a Lickert scale of 5 response options: very high $=5$, high $=4$, moderate $=$ 3 , Low $=2$ and very low $=1$. The ranges used to calculate the average of the results - Table 1.

The population object dee this research consisted of 846.609 subjects that make up the population of the department of La Guajira. The sampling was probabilistic (400 subjects). The samples were obtained by applying the following equation proposed 10 .

$$
\mathrm{n}=\frac{N \cdot Z_{c}^{2} \cdot p \cdot q}{(N-1) \cdot e^{2}+Z_{c} \cdot p \cdot q}
$$

Where:

$\mathrm{N}=$ Total population: 846,609 individuals.

$Z_{c}=$ Zeta critical or value is determined by the level of trust adopted. For a confidence level of $95 \%$ is equal to 2 , for a confidence level of $99 \%$ is equal to 3 .

$E=5 \%$ sampling error.

$\mathrm{p}=$ Proportion that presents a characteristic to be investigated (50).

Table 1. Description of values, intervals, alternatives and categories for the interpretation of the media

\begin{tabular}{|c|c|c|c|}
\hline Value & Intervals & Alternatives & Category \\
\hline 5 & $4.21-5.00$ & Totally agree & Very High \\
\hline 4 & $3.41-4.20$ & According & High \\
\hline 3 & $2.61-3.40$ & Moderately agree & Moderate \\
\hline 2 & $1.81-2.60$ & In disagreement & Low \\
\hline 1 & $1.00-1.80$ & Strongly disagree & Very Low \\
\hline
\end{tabular}


$\mathrm{q}=$ Proportion that do not present characteristics investigated; $\mathrm{p}+\mathrm{q}=1$.

The questionnaires were applied to and the results tabulated in an Excel sheet. The results were expressed in terms of absolute and relative frequencies, with the mean as a measure of central tendency and then graph the results in frequency histograms for analysis.

\section{Results and Discussion}

The result obtained corresponds to the studied dimensions: Digital accessibility, digital integration, equity and

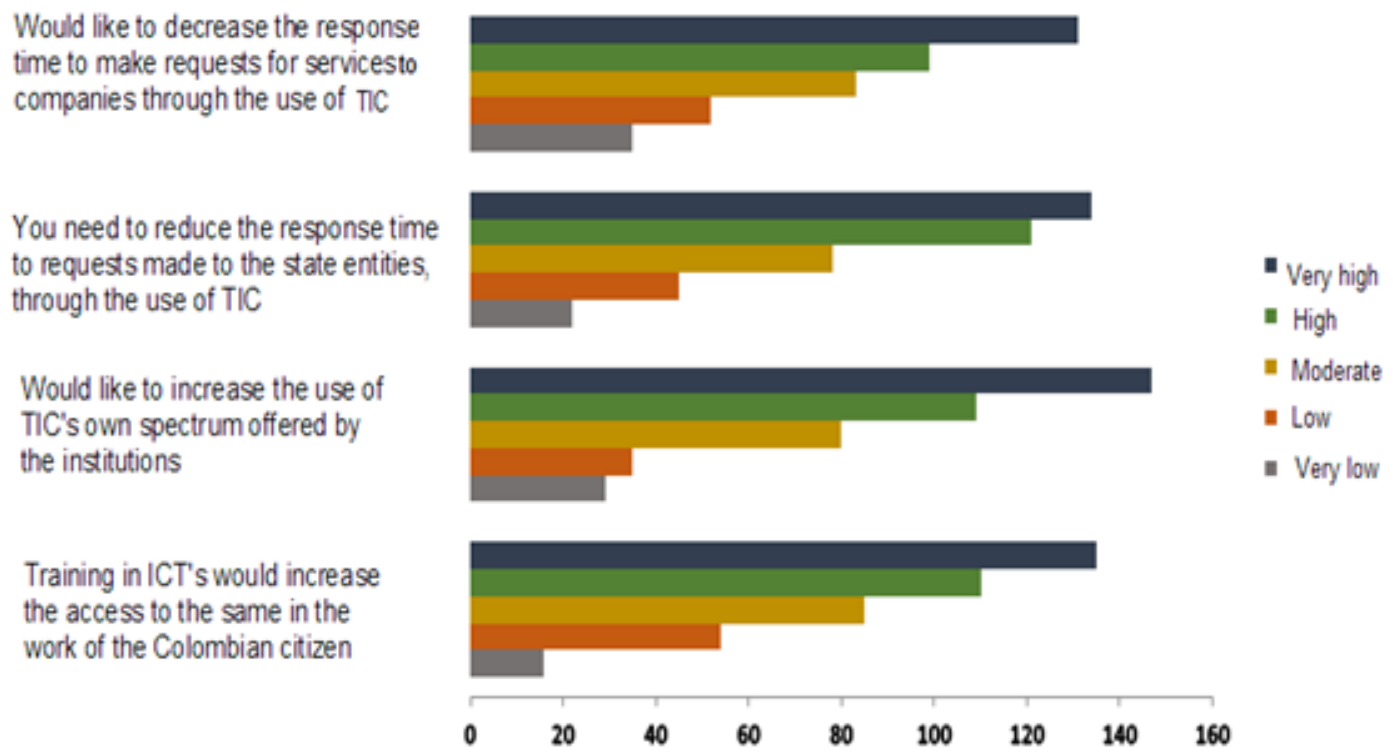

Figure 1. Distribution of absolute frequencies of the results on Digital Accessibility studied.

Table 2. . Distribucion de frecuencias absolutas para la dimension Accesibilidad Digital

\begin{tabular}{|c|c|c|c|c|c|c|}
\hline \multirow{2}{*}{ S.No } & \multirow{2}{*}{ Questions } & \multicolumn{5}{|c|}{ Answers } \\
\hline & & 1 & 2 & 3 & 4 & 5 \\
\hline 1 & $\begin{array}{l}\text { Training in TIC would increase the access to } \\
\text { the same in the daily work of the Colombian } \\
\text { citizen. }\end{array}$ & 16 & 54 & 85 & 110 & 135 \\
\hline 2 & $\begin{array}{l}\text { Would like to increase the use of spectrum of } \\
\text { TIC services offered by the institutions. }\end{array}$ & 29 & 35 & 80 & 109 & 147 \\
\hline 3 & $\begin{array}{l}\text { You need to reduce the response time to } \\
\text { requests made to the institutions of the State, } \\
\text { through the use of TIC. }\end{array}$ & 22 & 45 & 78 & 121 & 134 \\
\hline 4 & $\begin{array}{l}\text { Would like to decrease the response time to } \\
\text { make requests for services of the companies, } \\
\text { through the use of TIC. }\end{array}$ & 35 & 52 & 83 & 99 & 131 \\
\hline
\end{tabular}


management of employment. For each dimension is a table with the questions and absolute frequency of each alternative response, the frequency histogram graphically shows the behavior of the answers and finally, a table with the distribution of the relative and absolute frequencies, half of the dimension. Table 2 describes the absolute frequencies corresponding to the digital accessibility.
With the information in Table 2, a frequency histogram - Figure 1 there is a wide trend toward the categories of very high and high, while the other categories are observed with a very low number of responses.

For further analysis, Table 3 describes the absolute and relative frequencies and the arithmetic mean for each one of the questions on the dimension digital accessibility.

Table 3. Distribution of absolute frequencies (Fa) and relative (Fr) on the Digital Accessibility

\begin{tabular}{|c|c|c|c|c|c|c|c|c|}
\hline Question & \multicolumn{2}{|c|}{1} & \multicolumn{2}{|c|}{2} & \multicolumn{2}{|c|}{3} & \multicolumn{2}{|c|}{4} \\
\hline Response & $\mathrm{Fa}$ & $\operatorname{Fr}(\%)$ & $\mathrm{Fa}$ & Fr (\%) & $\mathrm{Fa}$ & $\operatorname{Fr}(\%)$ & $\mathrm{Fa}$ & Fr (\%) \\
\hline 1 & 16 & 4.50 & 29 & 7.25 & 22 & 5.50 & 35 & 8.75 \\
\hline 2 & 54 & 13.50 & 35 & 8.75 & 45 & 11.25 & 52 & 13.00 \\
\hline 3 & 85 & 21.25 & 80 & 20.00 & 78 & 19.50 & 83 & 20.75 \\
\hline 4 & 110 & 27.50 & 109 & 27.25 & 121 & 30.25 & 99 & 24.75 \\
\hline 5 & 135 & 33.75 & 147 & 36.75 & 134 & 33.50 & 131 & 32.75 \\
\hline Summation & 400 & 100.00 & 400 & 100.00 & 400 & 100.00 & 400 & 100.00 \\
\hline$\left(\sum\right)$ & \multicolumn{2}{|c|}{3.74} & \multicolumn{2}{|c|}{3.78} & \multicolumn{2}{|c|}{3.75} & \multicolumn{2}{|c|}{3.60} \\
\hline ( $\Sigma$ ) Dimension & \multicolumn{8}{|c|}{3.71} \\
\hline
\end{tabular}

Table 4. Distribution of absolute frequencies for Digital Inclusion

\begin{tabular}{|c|c|c|c|c|c|c|}
\hline \multirow{2}{*}{$\mathbf{N}$} & \multirow{2}{*}{ Question } & \multicolumn{5}{|c|}{ Response } \\
\hline & & 1 & 2 & 3 & 4 & 5 \\
\hline 1 & $\begin{array}{c}\text { The Colombian citizen interacts with its social environment } \\
\text { through the use of TIC. }\end{array}$ & 19 & 49 & 78 & 112 & 142 \\
\hline 2 & $\begin{array}{l}\text { Agrees to receive training for the digital literacy of the part } \\
\text { of the State }\end{array}$ & 12 & 28 & 95 & 118 & 147 \\
\hline 3 & $\begin{array}{c}\text { Agrees to receive training for the digital literacy of the part } \\
\text { of the Universities }\end{array}$ & 12 & 27 & 96 & 119 & 146 \\
\hline 4 & $\begin{array}{l}\text { Agrees to receive training for the digital literacy of the part } \\
\text { of the companies }\end{array}$ & 13 & 29 & 95 & 118 & 145 \\
\hline
\end{tabular}




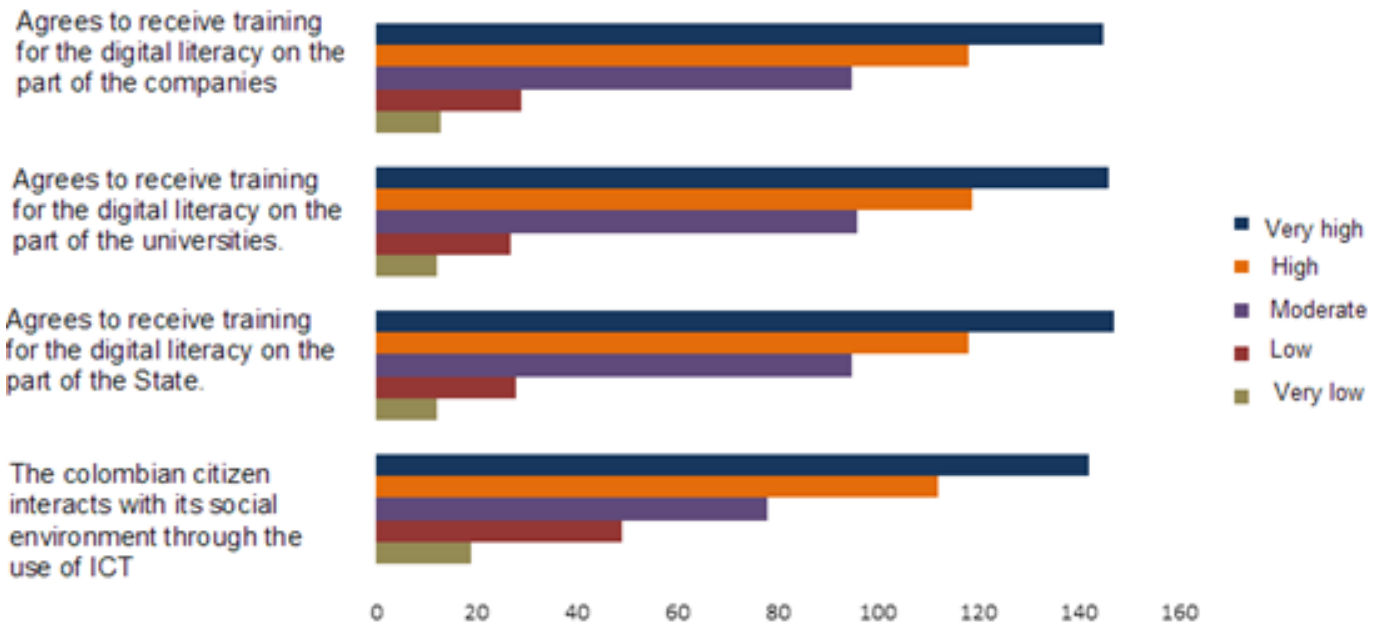

Figure 2. Distribution of absolute frequencies of the Digital Integration studied.

Table 5. Distribucion de frecuencias absolutas $(\mathrm{Fa})$ y relativas $(\mathrm{Fr})$ sobre la dimensión Inclusion Digital

\begin{tabular}{|c|c|c|c|c|c|c|c|c|c|c|}
\hline Question & \multicolumn{2}{|c|}{1} & \multicolumn{2}{|c|}{2} & \multicolumn{2}{|c|}{3} & \multicolumn{2}{|c|}{4} & \multicolumn{2}{|c|}{5} \\
\hline Response & $\mathrm{Fa}$ & $\operatorname{Fr}(\%)$ & $\mathrm{Fa}$ & $\operatorname{Fr}(\%)$ & $\mathbf{F a}$ & $\operatorname{Fr}(\%)$ & $\mathbf{F a}$ & $\operatorname{Fr}(\%)$ & $\mathbf{F a}$ & Fr (\%) \\
\hline 1 & 19 & 4.75 & 12 & 3.00 & 12 & 3.00 & 13 & 3.25 & 19 & 4.75 \\
\hline 2 & 49 & 12.25 & 28 & 7.00 & 27 & 6.75 & 29 & 7.25 & 49 & 12.25 \\
\hline 3 & 78 & 19.50 & 95 & 23.75 & 96 & 24.00 & 95 & 23.75 & 78 & 19.50 \\
\hline 4 & 112 & 28.00 & 118 & 29.50 & 119 & 29.75 & 118 & 29.50 & 112 & 28.00 \\
\hline 5 & 142 & 35.50 & 147 & 36.75 & 146 & 36.50 & 145 & 36.25 & 142 & 35.50 \\
\hline Summation & 400 & 100.00 & 400 & 100.00 & 400 & 100.00 & 400 & 100.00 & 400 & 100.00 \\
\hline$(\Sigma)$ & \multicolumn{2}{|c|}{3.77} & \multicolumn{2}{|c|}{3.90} & \multicolumn{2}{|c|}{3.90} & \multicolumn{2}{|c|}{3.88} & \multicolumn{2}{|c|}{3.77} \\
\hline$(\Sigma)$ Dimension & \multicolumn{10}{|c|}{3.86} \\
\hline
\end{tabular}

In Table 3 the average $(\Sigma)$ of the dimension 3.71 accessibility resulted in ranking in the category of High. This means that the majority of respondents believe that their training in ICT, increase their access to them in their daily work, especially in the use of the digital services offered by different institutions, reducing the time it used to take steps. This result, who argues that initiatives such as "Digital Kiosks Lives" in Colombia, facilitating access to ICTS to rural populations or of difficult access, articulating these virtual environments; linking online communication between subjects and education ${ }^{2}$. The above contributes to the development of the citizens in 
digital skills, be linked to their environment and external entities. For digital inclusion dimension, as in the previous dimension, the results of the absolute frequencies are described in Table 4.

The Figure 2 describes the absolute frequency, which can be observed in the trend toward Very High and High categories; the other categories are described a low number of responses.
Table 5 describes the absolute and relative frequencies of the dimension digital inclosing. The average $(\Sigma)$ was 3.86, placing the dimension digital inclusion in the category. According to the above, it is assumed that the Colombian people interact with the environment through ICT. In addition, receive training from the state, companies and/or universities. These results consider the digital inclusion as a human right related complex with the use

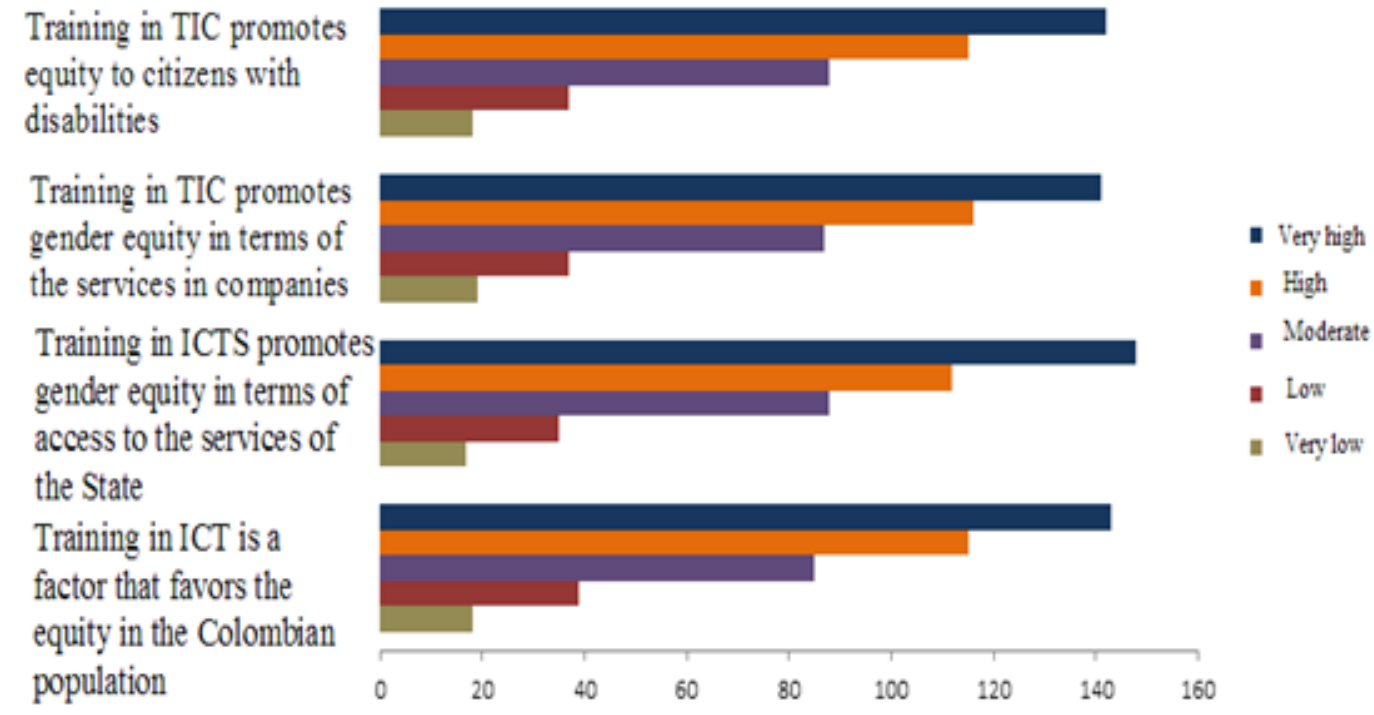

Figure 3. Distribution of absolute frequencies of the Equity studied.

Table 6. Distribution of absolute frequencies for the equity dimension

\begin{tabular}{|c|c|c|c|c|c|c|}
\hline \multirow{2}{*}{ N. } & \multirow{2}{*}{ Question } & \multicolumn{5}{|c|}{ Response } \\
\hline & & 1 & 2 & 3 & 1 & 5 \\
\hline 1 & $\begin{array}{l}\text { Training in TIC is a factor that favors the equity in } \\
\text { the Colombian population }\end{array}$ & 18 & 39 & 85 & 115 & 143 \\
\hline 2 & $\begin{array}{l}\text { Training in ICT promotes gender equity in terms of } \\
\text { access to the services of the State }\end{array}$ & 17 & 35 & 88 & 112 & 148 \\
\hline 3 & $\begin{array}{l}\text { Training in ICT promotes gender equity in terms of } \\
\text { access to the services of the companies }\end{array}$ & 19 & 37 & 87 & 116 & 141 \\
\hline 4 & $\begin{array}{l}\text { The ICT Training promotes equity of disabled } \\
\text { citizens }\end{array}$ & 18 & 37 & 88 & 115 & 142 \\
\hline
\end{tabular}


of ICT to stay connected and informed ${ }^{3}$. This thesis is reinforced believe that universities play a leading role in digital processes ${ }^{1}$.

Figure 3 describes the results obtained for the equity, it notes that the answers have a tendency toward the category very high, while the categories high, moderate, low and very low are represented by few answers.
Tables 6 and 7 describes the absolute and relative frequencies of outcomes related to the equity dimension. In this it is noted that the average $(\Sigma)$ was 3.82 , placing the digital inclusion in the category of High. This means that most of the respondents are in agreement with the use of ICTS as a means to promote equity in the population, both gender and of persons with disabilities. These results

Table 7. Distribution of absolute frequencies $(\mathrm{Fa})$ and relative $(\mathrm{Fr})$ on the equity dimension

\begin{tabular}{|c|c|c|c|c|c|c|c|c|c|c|}
\hline Question & \multicolumn{2}{|c|}{1} & \multicolumn{2}{|c|}{2} & \multicolumn{2}{|c|}{3} & \multicolumn{2}{|c|}{4} & \multicolumn{2}{|c|}{5} \\
\hline Response & $\mathrm{Fa}$ & $\operatorname{Fr}(\%)$ & $\mathbf{F a}$ & $\operatorname{Fr}(\%)$ & $\mathbf{F a}$ & Fr (\%) & $\mathrm{Fa}$ & $\operatorname{Fr}(\%)$ & $\mathrm{Fa}$ & $\operatorname{Fr}(\%)$ \\
\hline 1 & 18 & 4.5 & 17 & 4.25 & 19 & 4.75 & 18 & 4.5 & 18 & 4.5 \\
\hline 2 & 39 & 9.75 & 35 & 8.75 & 37 & 9.25 & 37 & 9.25 & 39 & 9.75 \\
\hline 3 & 85 & 21.25 & 88 & 22 & 87 & 21.75 & 88 & 22 & 85 & 21.25 \\
\hline 4 & 115 & 28.75 & 112 & 28 & 116 & 29 & 115 & 28.75 & 115 & 28.75 \\
\hline 5 & 143 & 35.75 & 148 & 37 & 141 & 35,25 & 142 & 35.5 & 143 & 35.75 \\
\hline Summation & 400 & 100 & 400 & 100 & 400 & 100 & 400 & 100 & 400 & 100 \\
\hline$(\Sigma)$ & \multicolumn{2}{|c|}{3.82} & \multicolumn{2}{|c|}{3.85} & \multicolumn{2}{|c|}{3.81} & \multicolumn{2}{|c|}{3.82} & \multicolumn{2}{|c|}{3.82} \\
\hline$(\Sigma)$ Dimension & \multicolumn{10}{|c|}{3.82} \\
\hline
\end{tabular}

Table 8. Distribution of absolute frequencies for the management dimension of employment

\begin{tabular}{|c|c|c|c|c|c|c|}
\hline \multirow{2}{*}{$\mathbf{N}$} & \multicolumn{2}{|c|}{ Questions } & \multicolumn{5}{c|}{ Answers } \\
\cline { 3 - 7 } & & 1 & 2 & 3 & 4 & 5 \\
\hline 2 & $\begin{array}{c}\text { Considers that training in ICT would facilitate their } \\
\text { access to employment. }\end{array}$ & 15 & 53 & 88 & 116 & 128 \\
\hline 3 & $\begin{array}{c}\text { The State should promote the establishment of a } \\
\text { database to facilitate the management of employment }\end{array}$ & 17 & 55 & 83 & 112 & 133 \\
\hline 4 & $\begin{array}{c}\text { ICT training required to use the web pages of } \\
\text { employment and integrate into the labor market. }\end{array}$ & 18 & 51 & 81 & 115 & 135 \\
\hline & $\begin{array}{c}\text { The knowledge in ICTS have in obtaining a better } \\
\text { salary }\end{array}$ & 22 & 49 & 79 & 110 & 140 \\
\hline
\end{tabular}


argue that the lack of communication and information affects the lives of people with disabilities, and does not allow them to social inclusion. It is important to generate a series of initiatives that these populations have development opportunities in society, through ICT. The results of the management of employment are described through absolute frequencies in Table 8.

The Figure 4 describes the tendency of the answers to the Very High and High categories, while remaining are observed with a very low number of responses. Table 9

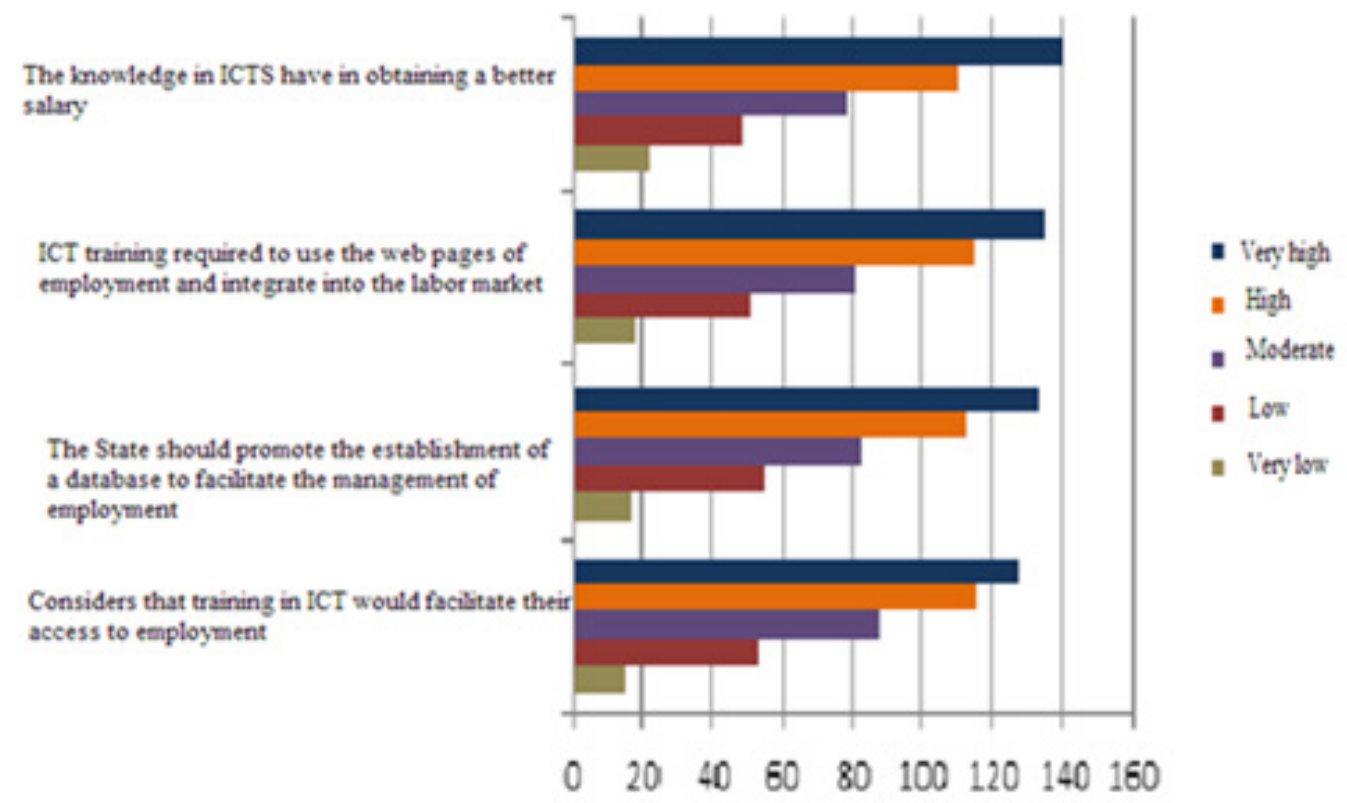

Figure 4. Distribution of absolute frequencies of the results on the management of employment.

Table 9. Distribution of absolute frequencies $(\mathrm{Fa})$ and relative ( $\mathrm{Fr})$ on the management of employment

\begin{tabular}{|c|c|c|c|c|c|c|c|c|}
\hline Question & \multicolumn{2}{|c|}{1} & \multicolumn{2}{c|}{ I } & \multicolumn{2}{c|}{ 3 } & \multicolumn{2}{c|}{ 4 } \\
\hline Answer & Fa & Fr (\%) & Fa & Fr (\%) & Fa & Fr (\%) & Fa & Fr (\%) \\
\hline 1 & 15 & 3,75 & 17 & 4,25 & 18 & 4,5 & 22 & 5,5 \\
\hline 2 & 53 & 13,25 & 55 & 13,75 & 51 & 12,75 & 49 & 12,25 \\
\hline 3 & 88 & 22 & 83 & 20,75 & 81 & 20,25 & 79 & 19,75 \\
\hline 4 & 116 & 29 & 112 & 28 & 115 & 28,75 & 110 & 27,5 \\
\hline 5 & 128 & 32 & 133 & 33,25 & 135 & 33,75 & 140 & 35 \\
\hline Summation & 400 & 100 & 400 & 100 & 400 & 100 & 400 & 100 \\
\hline$(\Sigma)$ & \multicolumn{2}{|c|}{3,72} & 3,72 & & 3,75 & & 3,74 \\
\hline
\end{tabular}


presents the distribution of absolute and relative frequencies related to the management of the employment.

Table 9 describes that the average reached a value of 3.73 which places the digital inclusion in the category of High. This means that most of the respondents agree that the training in ICTS facilitate access to the labour market if they are used, for example, tools such as bags of digital jobs. These results are argued through initiatives that facilitate access to ICT, rural populations or of difficult access, to contribute to the inclusion of these communities $^{2}$. We could look at the dimensions analyzed in this research that ICTS contribute significantly through the empowerment in the linking of the citizen in the development of the various key sectors of society. This gives you the ability to close the digital divide in such a way as to the inclusion is a feasible way through the education sector with strategies and capitalization of the university extension.

\subsection{Digital Empowerment Strategies for Sectors of Colombian Society}

The process of generating strategies begins with a diagnosis of the object of this study ${ }^{12,13}$. For this reason, the results of the digital empowerment from the education sector are capitalized with the university extension. This increases the accessibility and digital inclusion, equity, employment and management committed to sectors of society. In total proposes four strategies:

\subsection{Diagnosis of Levels of Citizen-Training in the use of TIC}

Actions: Diagnose the technological capacities that are required, and the capacity of universities to train human resources, technical and financial support.

\subsection{Orientation of the Training in all Courses Offered to Include Aspects Related to TIC}

Actions: To determine the programs to teach according to the social strata and the provision of digital skills to train personnel in the extension courses and development of multilingual platforms for disabled access.

\subsection{Joint University-State-Civil Society- Private Sector}

Actions: Search for the financing of the State and companies for development of diagnosis, development of content and digital platforms, invite employees of state and companies, to participate with teachers of the topics and design campaigns to inform the community about the services provided by the university.

\subsection{Promotion of Projects for Digital Inclusion in the Communities}

Actions: Identify digital inclusion projects that can develop communities, search and training of entrepreneurs of digital inclusion projects.

\section{Conclusions}

The Colombian citizen believes in a very high degree that the ICT training increases their access in the daily. The digital inclusion is considered to be very high degree that interacts with their social environment through the use of ICT. This requires the need to receive training on the part of the universities and companies. It is considered that equity is achieved in a very high degree to the extent that the ICT training favours the Colombian population especially when it relates to gender and care of people with disabilities in the provision of state services and companies.

In relation to the management of employment, believes in a very high degree that the ICT training makes it easy to access. It is estimated that, the State must promote the creation of data bases where the training requirements that include, for example, the use of web pages of employment. Depending on the results, it can be concluded that the university has an opportunity to educate the digital citizens, increase their actions of empowerment. Finally, it must be recognized that the conditions are given for that Colombia can deploy digital inclusion policies that 
empower their fellow citizens by the rise in the levels of access to the internet and the digital inclusion public policies developed through the Ministry of Information Technologies and Communications.

\section{References}

1. Ortiz M, Morales M. La extension universitaria en America Latina: Concepciones y tendencias. Educacion y Educadores. 2011; 14(2):349-66.

2. Builes C. Kioscos vive digital: Una estrategia digital y de conectividad para promover la inclusion social en comunidades rurales en Colombia. International Journal of Psychological Research. 2016; 9(1):126-30. Crossref.

3. Torre L, Dominguez J. Las TIC en el proceso de ense-anza aprendizaje a traves de los objetos de aprendizaje. Revista Cubana de Informática Medica. 2012; 4(1):8392.

4. Torres J. La fundamentacion del derecho a la inclusion digital. Revista Prolegomenos. Julio-Diciembre. 2015; 18(36):4764 .

5. Fernandez A, Nairouz Y. Uso de tecnologías de informacion y comunicacion por personas con discapacidad en Bibliotecas Mayores de Bogota. Revista de la Facultad de Medicina. 2017; 61(2):30-8.
6. Jimenez -Pitre IA, Martelo Gomez RJ, Chiquillo RJ, Lloreda GD, Morales CS. Estrategias para el empoderamiento digital y la integracion de universidades con sectores clave para la sociedad colombiana. Revista Lasallista de Investigación. 2017; 14(1):112-25. Crossref.

7. Schiavo E, Dos Santos C, Vera P. Entre la divulgacion de la cultura digital y el surgimiento de los laboratorios ciudadanos. El caso argentino en el contexto latinoamericano. Revista iberoamericana de Ciencia, Tecnologia y Sociedad. 2013; 8(23):179-99.

8. Jimenez-Pitre IA, Martelo RJ, Jaimes JDC. Escuela de Gobierno basada en TIC: Determinante para la Accesibilidad e Integralidad del Empoderamiento Digital. Información Tecnologica. 2017; 28(5):75-86. Crossref.

9. Alzina RB. Metodologia de la investigacion educativa. Madrid: Editorial La Muralla; 2011.

10. Hernandez-Sampieri R, Fernandez-Callado C, BaptistLucio P. Libro Metodologia de la investigacion. 6th Ed. Mexico: McGraw-Hill; 2016.

11. Ruiz-Bolivar C. Instrumentos de Investigacion Educativa Barquisimeto (Venezuela): Ediciones CIDEG, C.A.; 1998.

12. David F. Conceptos de administracion estratégica. 9th Ed. Mexico DF: Pearson Prentice Hall; 2003. p. 1-368.

13. Dominguez AG. El derecho fundamental a la proteccion de datos personales en el ambito de la justica europea. Revista Aporia Juridica. 2017; 1:45-70. 